\title{
Limitations on recruitment of the rare sand daphne Pimelea arenaria (Thymelaeaceae), lower North Island, New Zealand
}

P. A. C. DAWSON

G. L. RAPSON*

A. W. ROBERTSON

R. A. FORDHAM

Ecology Group

Institute of Natural Resources

Massey University

Private Bag 11-222

Palmerston North, New Zealand

*Author for correspondence:

G.Rapson@massey.ac.nz.

\begin{abstract}
Pimelea arenaria, an endangered native sand dune plant, appears to be experiencing recruitment failure. The structure of four populations from the lower North Island, New Zealand, was examined for recruitment patterns, while one population was examined for flowering, pollination, and seed germination limits on regeneration. Line transects and searches found no seedlings, and measures of individual plant sizes $(n=331)$ showed bias towards medium, with some large, individuals, suggesting recruitment failure at all sites. Flowers are plentiful. The standing crop of nectar was c. $0.4-0.9$ joules per hermaphrodite flower, with insects appearing to be the main pollen vectors. Pollination manipulations were carried out on both genders at one site, with fruit set measured from natural, hand out-crossed, and pollinator-exclusion treatments. Female flowers do not appear to be pollen limited as natural fruit set is only non-significantly lower than that in hand-outcrossed flowers. Only hermaphrodite plants selfed autonomously, with nearly $90 \%$ producing fruit. One quarter of the seed from both female and hermaphrodite flowers germinated. Results suggest that recruitment failure of Pimelea arenaria is not due to reproductive biology, pollen limitation, or poor seed
\end{abstract}

B04025; Online publication date 15 July 2005 Received 7 July 2004; accepted 13 May 2005 germination. Therefore, recruitment failure probably occurs during the seedling establishment phases, due to environmental pressures and/or predation.

Keywords Pimelea arenaria; sand dunes; regeneration; pollination; fruit set; population structure

\section{INTRODUCTION}

Since people arrived in New Zealand there has been a $70 \%$ reduction in the area of active coastal dune lands (Hilton et al. 2000) to 39000 ha. This, combined with threats from urbanisation, forestry, and agricultural development, has meant that many native dune species have declined in abundance or become regionally extinct (Fig. 1; Milne \& Sawyer 2002). One such native plant is Pimelea arenaria A.Cunn. (Thymelaeaceae), the rare sand daphne, which is now restricted to four main areas: Northland (south to Auckland on the west coast and Thames on the east coast), the lower North Island to the Nelson region, the Chatham Islands, and a small area around Dunedin (South Island), although this last population is now thought to be extinct (Heads 1994). Pimelea arenaria is confined to coastal sand dunes on the lee of the fore dune (Fig. 2; Esler 1978; Heads 1994; pers. obs.), and is listed as Chronically Threatened and Gradually Declining (de Lange et al. 2004). Anecdotal evidence suggests this is due to a recruitment failure (C. Ogle, A. Dijkgraaf, Department of Conservation, pers. comm.). Fruit or seedlings are rarely observed in the wild (C. Ogle, D. Ravine, Department of Conservation, pers. comm.; pers. obs.), despite the potential for a large fruit crop with Pimelea arenaria flowering profusely.

Pimelea arenaria is a semi-prostrate woody plant, with decussate, elliptic, hairy leaves approximately $5 \mathrm{~mm}$ long (Allan 1961; Milne \& Sawyer 2002). Flowers are tubular with a white perianth, 5-7 mm long (Allan 1961), grouped in small inflorescences of four flowers each (pers. obs.). It is a gynodioecious species (Burrows 1958, 1960), with hermaphrodite flowers distinguishable from the females (Fig. 2) by 


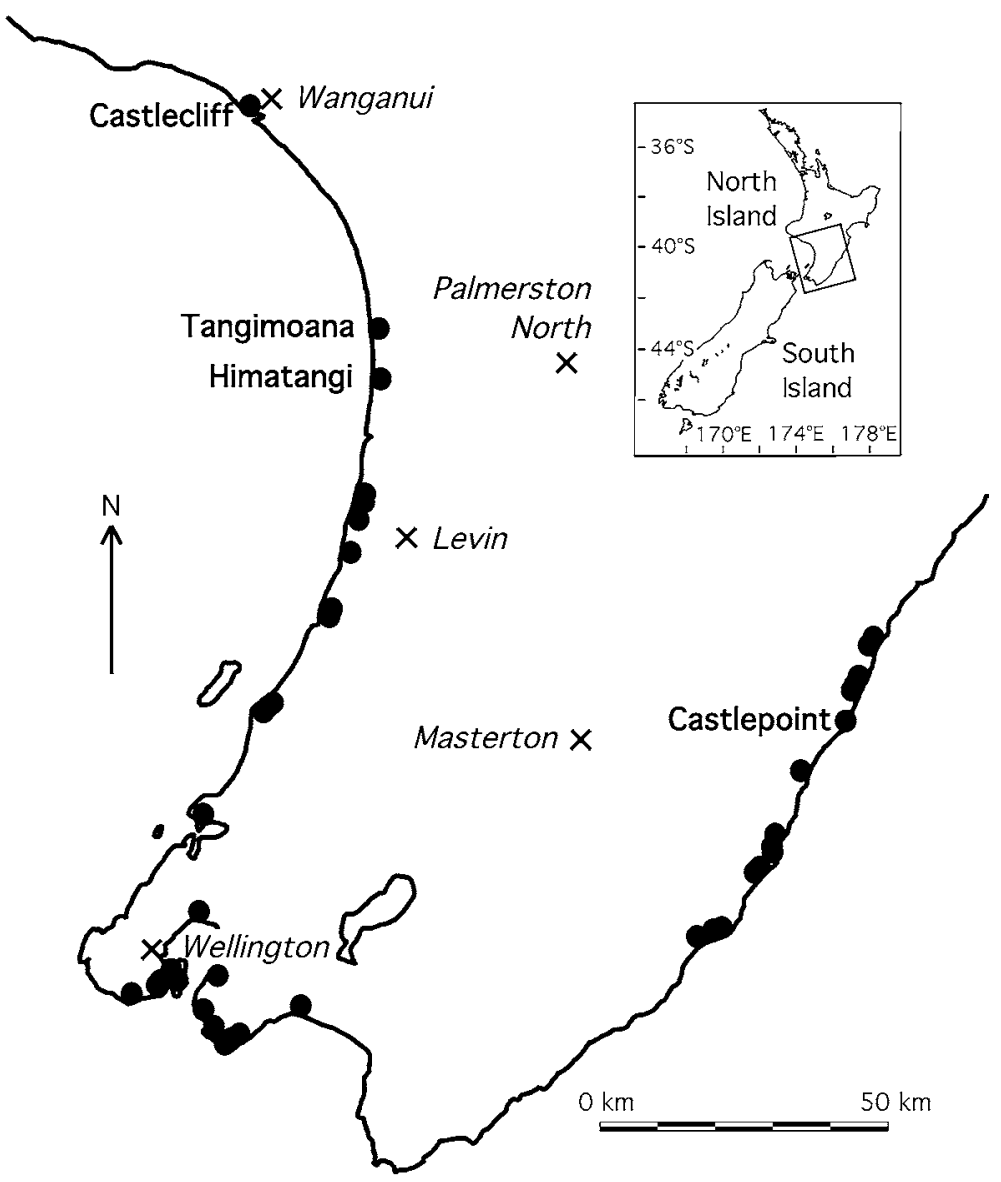

Fig. 1 The current distribution $(\bullet)$ of Pimelea arenaria in southern North Island, New Zealand (Milne $\&$ Sawyer 2002), and the four study sites. $x$, urban areas in italics.

two prominent yellow/orange anthers that project from the floral tube. Although most of a plant will be one or other flower type (pers. obs.), the occurrence of isolated flowers (Burrows 1958, 1960) or even terminal branches (pers. obs.) of the other flower type complicates gender assignment. Fruit are about $3 \mathrm{~mm}$ long, white or red, with a pulpy mesocarp, and contain a single seed.

Pimelea ecology has received little attention in the literature. The first reports on any New Zealand Pimelea species were by Parlane (1925) and Burrows (1958), examining the habitat, and reproductive and vegetative variation, between individuals and populations from the Cass Valley, Canterbury. Burrows (1960) examined the breeding systems of Pimelea spp., including $P$. prostrata, $P$. traversii, and $P$. oreophila. Recent work has looked at toxins found in the Thymelaeaceae, including Pimelea (Freeman et al. 1979; Adolf \& Heckler 1982; Zayed et al. 1982; Hafez et al. 1983; Pettit et al. 1983; Adolf et al. 1988), and at biogeography of New Zealand Pimelea (Heads 1994).

This paper uses four separate Pimelea arenaria populations in the lower North Island: Castlecliff, Tangimoana (at Tawhirihoe Scientific Reserve), and Castlepoint, all on Department of Conservation estate, and Himatangi on private land (Fig. 1) to examine recruitment failure, addressing three questions:

1. Is a lack of recruitment (an absence of smaller size classes in an otherwise continuous frequency distribution) apparent from the population structure?

2. Do plants flower and set seed?

3. If any seed is produced, is it able to germinate? 

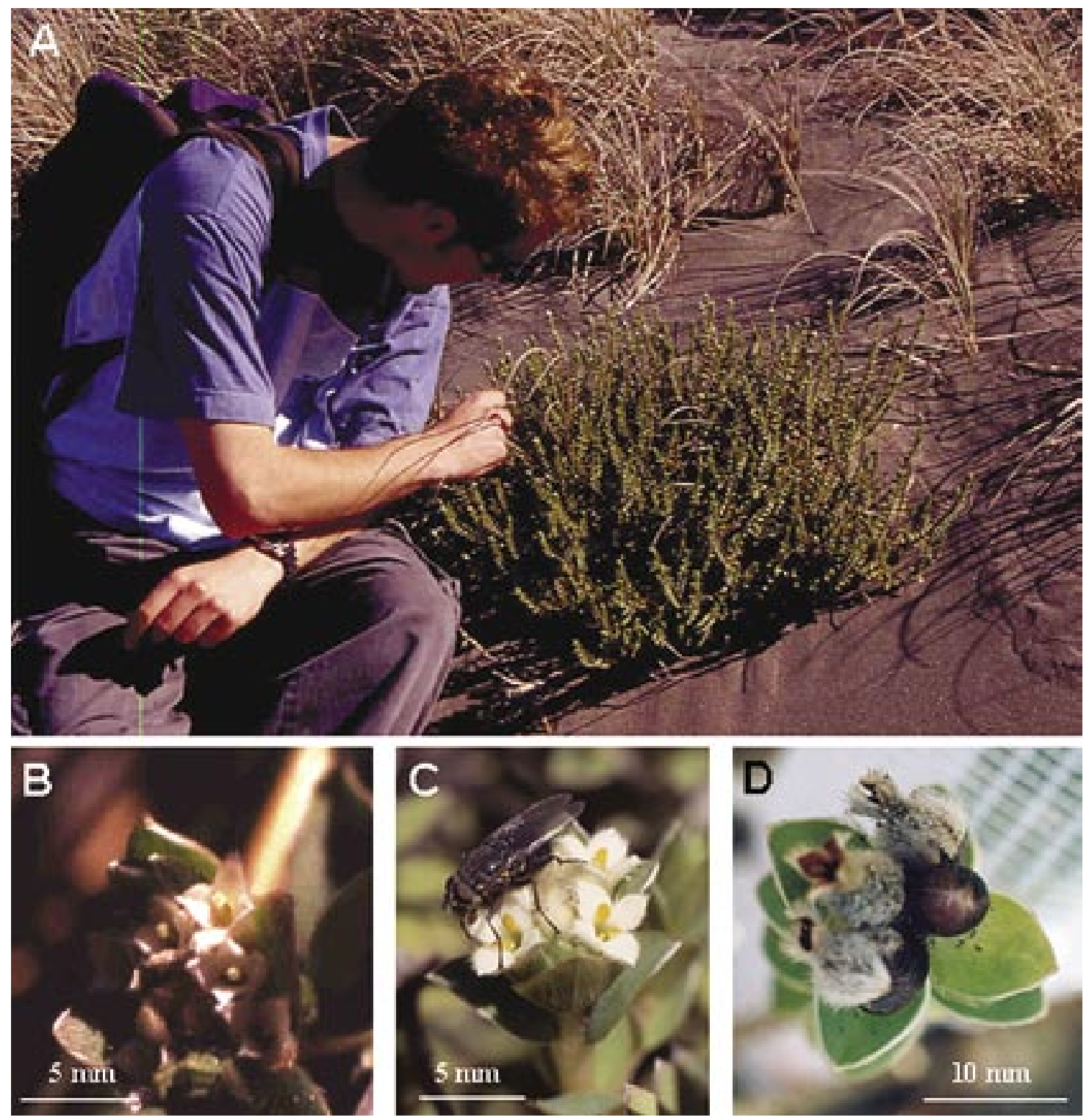

Fig. 2 A, A plant of Pimelea arenaria, amongst the sand binder Spinifex sericeus R.Br. (Tangimoana, May 2002); $\mathbf{B}$, female flowers; $\mathbf{C}$, hermaphroditic flowers with visiting fly, probably a Sacrophagid; D, red fruit (Tangimoana, January 2003). (Photos: A, G. L. Rapson; B-D, P. A. C. Dawson)

\section{METHODS}

\section{Population structure}

The total population was counted at each of the four sites during December 2002. A separate search was made for seedlings using transects. A $50 \mathrm{~m}$ transect was laid through the most abundant patches of Pimelea arenaria at each site parallel to the surf line, and, at $5 \mathrm{~m}$ intervals, a careful search was made for seedlings in a circle of $1 \mathrm{~m}$ radius. To investigate the density of the populations, the distance $(\mathrm{cm})$ to the nearest neighbour (edge to edge) of 10 randomly selected plants at each site was also measured.

Twenty plants were selected randomly from each population, and, in a $2 \times 2 \mathrm{~m}$ square centred on each plant, slope and aspect were measured along 
the line of greatest slope; smaller areas were used at Castlepoint where sand drift occurred between rock outcrops. Average northingness of aspect (true north), a measure of solar exposure, was calculated from the cosines of the angles (in radians for Microsoft Excel).

As Pimelea species are unable to be aged by growth rings (Burrows 1958), height and plant area were assumed to be positively correlated with age. An estimate of the total surface area of substrate covered by each plant was obtained by measuring its greatest length parallel to the surf line, and width at right angles thereto, and calculating plant area $=\pi$ $\times 0.25$ (length $\times$ width), which assumes an elliptical shape. Maximum height above the substrate was measured at the centre of the plant.

Because both genders were not present at all sites, the plant area and height data were first analysed for differences between genders over all sites, excluding plants with unknown genders, which were either too young to flower, or were already setting fruit at the time of recording. Then data were analysed within each gender for differences between sites. Analysis used General Linear Models in Systat (1996), which assume a Gaussian error distribution. Data were double square root transformed (Quinn \& Keough 2002) prior to analysis to normalise the data.

\section{Floral and pollination biology}

Because the functional gender of an individual can vary across the plant (Burrows 1958, 1960; pers. obs.), the gender was determined from the predominant flower type in December 2002. Some plants with only fruit present were excluded from the gender ratio calculation as it was not possible to distinguish female from hermaphrodite plants in the absence of flowers.

Single time (December 2002) estimates of floral density (flowers $/ \mathrm{m}^{2}$ of plant area) were obtained from 6 photographs, 2 from Castlepoint and 4 from Tangimoana, that each showed an entire plant of known area from an aerial perspective. All inflorescences were counted and then multiplied by four (as almost all inflorescences contain four flowers; pers. obs.) to give the number of flowers.

From each of Castlepoint and Castlecliff, 23 unopened flower buds were collected and preserved in 3:1 ethanol:acetic acid. The anthers were extracted, crushed in $0.3 \mathrm{ml}$ mannitol solution and coloured with a little aceto-carmine, and pollen grains counted using a haematocytometer slide (Kearns \& Inouye 1993).
Nectar samples were taken from 12 individual hermaphrodite plants at Castlepoint and 14 at Castlecliff using filter paper wicks in late December 2002, and again in early January 2003, between 0800 and $0930 \mathrm{hr}$ NZDST. Wet wicks were air-dried in the field, then placed in sealed containers for transport back to the laboratory (modified from Kearns \& Inouye (1993). Nectar samples were analysed using an anthrone colorimetric assay to determine total sugar content, and the standing crop of nectar was then calculated, following McKenna \& Thomson (1988), in $\mu \mathrm{g}$ sucrose equivalents from a standard sucrose curve. Data were then converted to joules, assuming that $1 \mathrm{mg}$ sucrose equates to 16.48 joules of energy (Kearns \& Inouye 1993). Differences between populations were analysed by a two-tailed $t$-test, assuming equal variance. The nectar content in female flowers was not recorded.

The Castlepoint site was used to assess fruit set under different pollination treatments because of the large number of accessible female and hermaphrodite individuals. In early January 2003, 8 hermaphrodite and 8 female plants were selected at random. Three branches were selected on each individual and one of the following treatments was randomly applied to each. (1) Natural pollination consisted of tagging 10 inflorescences that were losing floral parts and had had the opportunity to be pollinated via naturally occurring vectors. (2) Hand out-crossed pollination of young flowers used pollen collected from 10 other plants in the reserve earlier in the day. Anthers were combined and crushed in a vial to release the pollen, which was then applied to the style on each of the flowers on the selected branches using a thin rod. (3) The pollinator-exclusion treatment used unopened flowers over which a mesh bag was placed to prevent pollinator access. Following fruit set, the other treatments were also bagged to prevent fruit predation or removal. The resulting fruits were harvested in March 2003. The proportion of fruit set was analysed separately for female and hermaphrodite plants using a binomial (there being only two possible outcomes: fruit set or not set) Generalised Linear Model in S-Plus 4.5 (1998), treating plants as blocks, and utilising a logit link function. Post-hoc tests using Least Significant Differences from S-Plus compared treatments where the model indicated significant effects.

\section{Germination ecology}

In the laboratory the harvested fruits from each pollination treatment were counted and weighed individually. The seeds were extracted and weighed, 
and the pulp fresh weight was calculated to determine fruit size. The seeds were then placed on water-soaked blotting paper in a $20^{\circ} \mathrm{C}$ constant temperature room with a 12 hour light/dark cycle, a treatment in which germination most often occurs for all species (C. McGill, Massey University, pers. comm.). Because the available fruit resulted in an unbalanced design, fruit, pulp, and seed fresh weight data were analysed separately within genders. Treatment effects were tested using General Linear Models in Systat (1996). Seed germination data were analysed separately for each gender by Chi-square. The single seed set in the female pollinator-excluded treatment was omitted.

\section{RESULTS}

\section{Population structure}

At Castlepoint, half the Pimelea arenaria plants are growing on sand drifts against a limestone outcrop, locally known as the Reef, and the rest are on the dunes fringing the Lagoon. At the other sites, the plants occur immediately behind the foredunes. Habitats of all the individuals are steep (Table 1), with $5 \%$ of individuals found on slopes greater than $45^{\circ}$, on the cliff face of the Reef at Castlepoint. Pimelea arenaria plants tend to occur on south-facing slopes, except at Himatangi (Table 1), though aspect is variable.
Over the 4 sites a total of 331 plants was recorded. The line transects, intensively searching $34.5 \mathrm{~m}^{2}$ at each of the four sites, found no seedlings, and none was observed at any site in the course of other work (areas of approx. $0.1 \mathrm{~km}^{2}$ ).

The Pimelea arenaria populations had plant areas averaging 1.1 to $2.2 \mathrm{~m}^{2}$ (Table 1; Fig. 3), and $95 \%$ of the plants at each site were less than $6 \mathrm{~m}^{2}$. Castlepoint and Himatangi had the largest proportion of plant areas greater than $6 \mathrm{~m}^{2}$; all were hermaphroditic (Fig. 3). There were no plants with areas less than $0.1 \mathrm{~m}^{2}$ at Castlepoint, and only 1 , 1 , and 3, respectively, at Castlecliff, Tangimoana, and Himatangi. However, there were no significant differences in plant area between sites (Table 2). Although plants of unknown gender tended to be less than one third of the size of plants of known gender (Fig. 3), there were no significant differences between females and hermaphrodites in plant area $(P>0.5$, Error d.f. $=323$, Error M.S. $=0.07)$.

There were no significant differences in height between females and hermaphrodites $(P>0.6$, Error d.f. $=323$, Error M.S. =0.13). Though hermaphrodite plants differed significantly in height between sites (Tables 1 and 2), females did not $(P>0.6$, Error d.f. $=21$, Error M.S. $=0.1)$. The tallest hermaphroditic plants were found at Castlepoint and Tangimoana (Table 1). There were few plants less than $100 \mathrm{~mm}$ in height, though most were below $400 \mathrm{~mm}$. There was no correlation between height and plant area.

Table 1 Location, habitat, population, and reproductive characters of the four studied populations of Pimelea arenaria. Values are means \pm standard error of the mean. The aspect and slope are taken from 20 random plants at each site, with average northingness from the cosine of the angle, where $1=$ North, $-1=$ South, and East $=$ West $=0$. n.d., no data.

\begin{tabular}{lcccc}
\hline Parameter & Castlecliff & Tangimoana & Himatangi & Castlepoint \\
\hline Latitude & $39^{\circ} 56^{\prime} \mathrm{S}$ & $40^{\circ} 19^{\prime} \mathrm{S}$ & $40^{\circ} 23^{\prime} \mathrm{S}$ & $40^{\circ} 54^{\prime} \mathrm{S}$ \\
Longitude & $174^{\circ} 57^{\prime} \mathrm{E}$ & $175^{\circ} 14^{\prime} \mathrm{E}$ & $175^{\circ} 14^{\prime} \mathrm{E}$ & $176^{\circ} 14^{\prime} \mathrm{E}$ \\
Total no. of plants on site & 46 & 80 & 118 & 87 \\
Average slope $\left({ }^{\circ}\right)$ & $19.6 \pm 14.2$ & $19.6 \pm 10.5$ & $23.0 \pm 10.9$ & $32.6 \pm 25.6$ \\
Aspect (northingness) & $-0.60 \pm 0.70$ & $-0.18 \pm 0.78$ & $0.13 \pm 0.80$ & $-0.24 \pm 0.69$ \\
Smallest plant area (m) & 0.061 & 0.038 & 0.038 & 0.139 \\
Mean plant area (m) & $1.06 \pm 0.12$ & $1.81 \pm 0.17$ & $2.16 \pm 0.28$ & $2.17 \pm 0.28$ \\
Largest plant area (m) & 4.00 & 6.02 & 17.04 & 15.97 \\
Mean height of hermaphrodite plants (m) & $0.21 \pm 0.02$ & $0.29 \pm 0.04$ & $0.21 \pm 0.01$ & $0.27 \pm 0.03$ \\
Nearest neighbour distance (m) & $3.08 \pm 0.58$ & $3.83 \pm 0.97$ & $2.17 \pm 0.44$ & $0.93 \pm 0.07$ \\
Gender ratio (female:hermaphrodite) & $0: 1$ & $1: 14.2$ & $1: 17.8$ & $1: 5.6$ \\
Nectar reward of hermaphrodite flowers & $0.41 \pm 0.035$ & n.d. & n.d. & $0.96 \pm 0.069$ \\
$\quad$ joules) & & & & \\
\hline
\end{tabular}



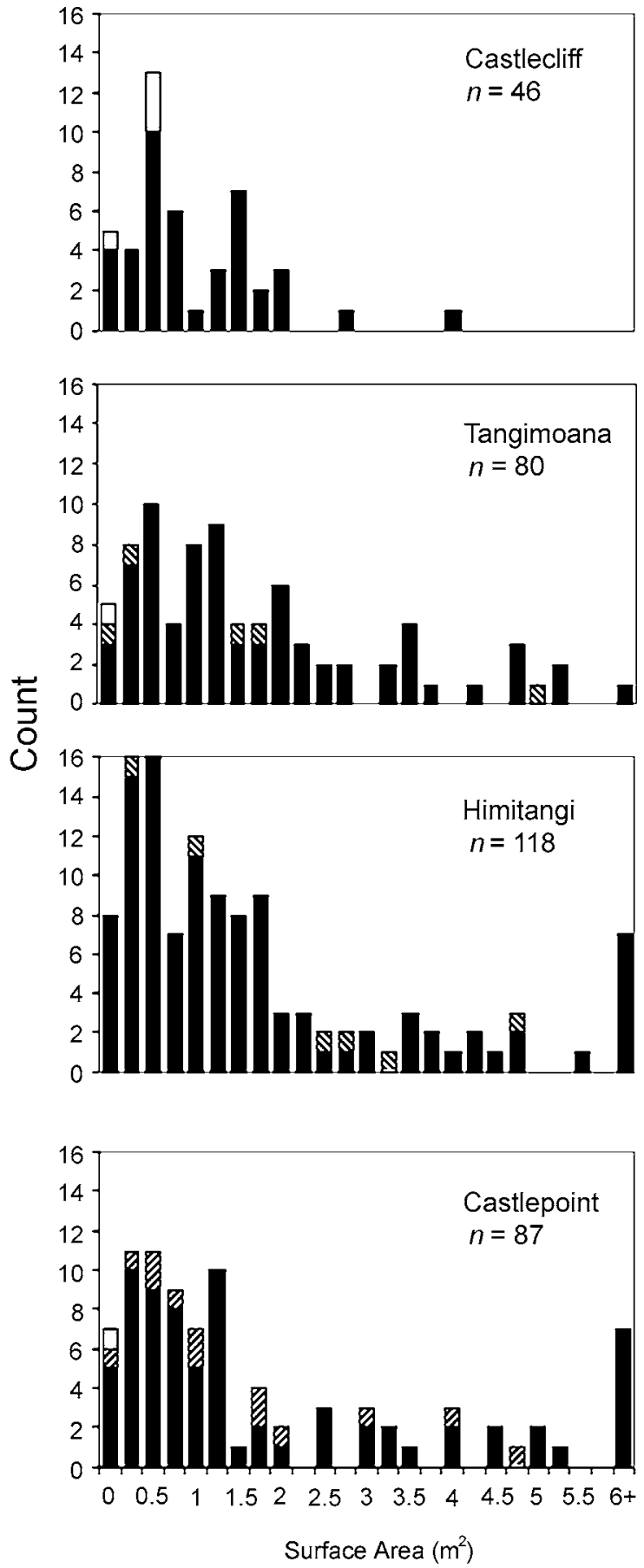

Fig. 3 Distributions of plant area (of substrate surface covered) for Pimelea arenaria plants of hermaphrodite (solid bars), female (hatched bars), and unknown (open bars) genders, at the four sites (December 2002). N, the number of plants at each site. Alternate bars on the $x$ axis are labelled with the lower bound.
At Castlepoint, plant density was greatest, as nearest neighbour distances were uniformly small $(0.93 \pm 0.07 \mathrm{~m})$, though the other sites had greater variation around larger distances between individuals (Table 1).

\section{Floral and pollination biology}

Population gender ratios varied between sites (Table 1). At Castlecliff only hermaphrodite plants were found, and hermaphrodites were always more common than female plants at all sites in December 2002.

Pimelea arenaria flower density was 423 ( \pm $99 \mathrm{SE}$ ) flowers $\mathrm{m}^{-2}$ ( $n=6$ plants). There was a single ovule in each fruit (Fig. 2). The pollen: ovule ratio was 1987 ( \pm 172$): 1$. Nectar was present in hermaphrodite plants at both Castlecliff and Castlepoint, the average standing crop being twice as high at Castlepoint $(P=0.049$; Table 1$)$.

Fruit set of hermaphrodites was consistently high in all pollination treatments including pollinator-exclusion (Fig. 4), with no significant difference between treatments (Table 3). In females, fruit set was generally lower and varied significantly with pollination treatment (Table 3 ). Though natural pollination produced only two thirds the fruit of hand out-crossed flowers, these treatments did not differ significantly. However, they were both different from the pollinatorexclusion treatment, where fruit set was close to zero (Fig. 4), the only seed set presumably due to pollen contamination in the bag. Thus, there was no evidence for pollen limitation in either gender, and there were high rates of autonomous selfing in hermaphrodites but not females.

\section{Germination ecology}

Weights of fruit, seed, and fruit pulp produced by hermaphrodites differed significantly between the three treatments $(P<0.01$, Error d.f. $=70$, Error M.S. $<0.001$ for all variates), seeds being smaller in the naturally pollinated treatment, and fruit and pulp weight less for the pollinator-exclusion treatment (Table 4). There were no significant treatment effects for seed of females $(P>0.5)$. Germination rates of seed were generally low (averaging $29 \%$; Table 4). Germination of seed produced by hermaphrodites did not vary with treatment $\left(\chi^{2}=0.861, P=0.650\right)$, while germination of naturally pollinated seed of females was significantly lower than hand out-crossed seed $\left(\chi^{2}=4.0381\right.$, $P=0.044)$. 


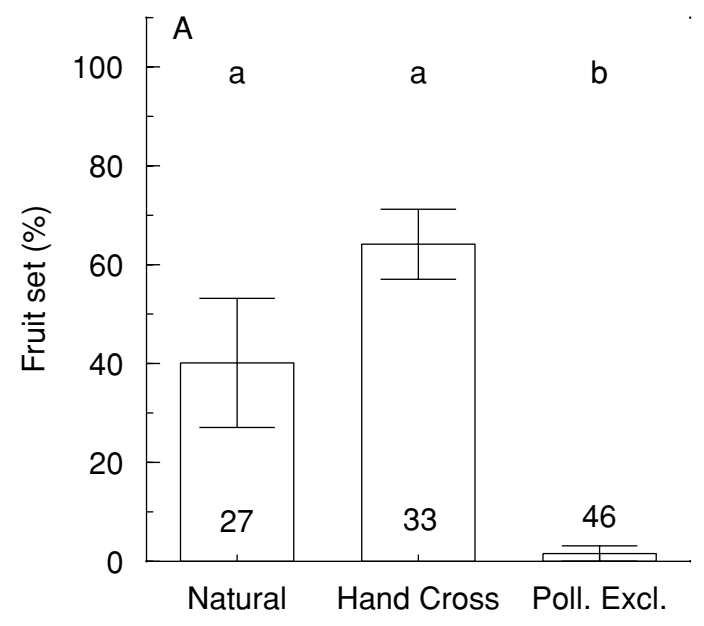

Treatment

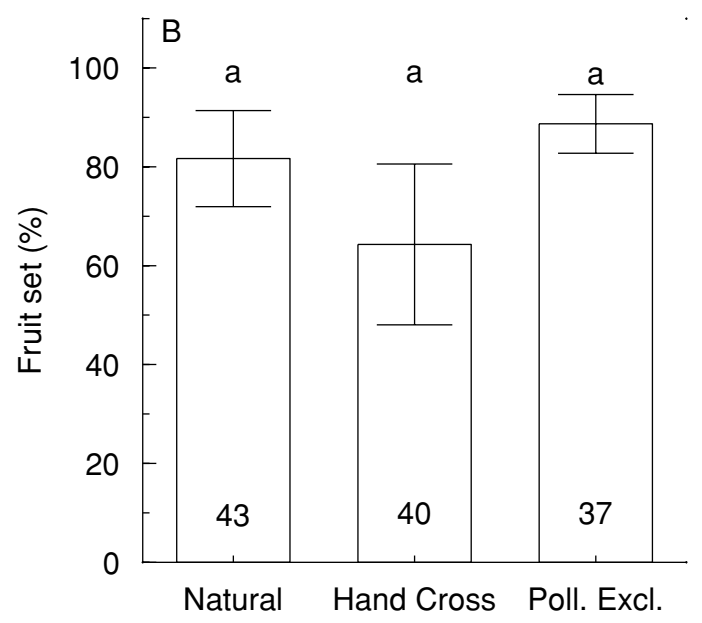

Treatment

Fig. 4 Fruit set (mean \pm SE) in $\mathbf{A}$, female and $\mathbf{B}$, hermaphrodite plants of Pimelea arenaria from Castlepoint following three pollination treatments: natural, buds tagged but otherwise not manipulated; hand out-crossed, "Hand Cross", supplemental pollen painted onto stigmas; and pollinator-excluded, "Poll. Excl.", buds enclosed in mesh bags to exclude pollinators). Letters $a$ and $b$ represent treatments within a gender not significantly different from each other according to range tests. Numbers are numbers of flowers manipulated.

Table 2 General Linear Model analysis of measures of plant size (area and height), for each gender. Data were double square root transformed prior to analysis. Significant $P$ values are in bold.

\begin{tabular}{lllrccc}
\hline Gender & Variate & Factor & d.f. & Mean square & $F$-ratio & $P$ value \\
\hline Female & Plant area & Site & 2 & 0.032 & 0.445 & 0.647 \\
& & Residual & 21 & 0.072 & & \\
& Plant height & Site & 2 & 0.049 & 0.497 & 0.615 \\
& & Residual & 21 & 0.098 & & \\
Hermaphrodite & Plant area & Site & 3 & 0.152 & 2.011 & 0.113 \\
& & Residual & 297 & 0.076 & \multirow{2}{*}{13.326} & $\mathbf{0 . 0 0 0}$ \\
& Plant height & Site & 3 & 1.629 & & \\
& & Residual & 297 & 0.122 & & \\
\hline
\end{tabular}

Table 3 Binomial Generalised Linear Model analysis of fruit set in female and hermaphrodite Pimelea arenaria plants from Castlepoint. Plants were entered first as blocks, and treatments (natural, hand out-crossed, and pollinator-excluded) added second. Significant $P$ values are in bold.

\begin{tabular}{llrccc}
\hline \multicolumn{1}{c}{ Plant type } & Factor & d.f. & Deviance & $F$-ratio & $P$ value \\
\hline Female & Plant & 7 & 17.08 & 1.075 & 0.431 \\
& Treatment & 2 & 43.37 & 9.556 & $\mathbf{0 . 0 0 3}$ \\
Hermaphrodite & Residual & 13 & 15.95 & & \\
& Plant & 6 & 5.28 & 0.293 & 0.928 \\
& Treatment & 2 & 7.15 & 1.191 & 0.340 \\
& Residual & 11 & 37.38 & & \\
\hline
\end{tabular}


Table 4 Fruit, wet seed, and fresh pulp weight (mean \pm standard error) of fruits obtained through the pollination manipulation experiment, and germination success of these seeds at a constant $20^{\circ} \mathrm{C}$ and in 12 hour light/dark conditions after 5 months. No. of fruit for all variates, except where noted, in parentheses.

\begin{tabular}{llccc}
\hline & & \multicolumn{3}{c}{ Treatment } \\
\cline { 3 - 4 } Variate & \multicolumn{1}{c}{ Gender } & Natural & Hand out-crossed & Pollinator-exclusion \\
\hline Fruit fresh weight $(\mathrm{mg})$ & Hermaphrodite & $86.3 \pm 5.3(24)$ & $77.7 \pm 6.1(23)$ & $65.4 \pm 3.9(26)$ \\
& Female & $78.1 \pm 5.5(18)$ & $79.8 \pm 3.4(23)$ & - \\
Pulp fresh weight $(\mathrm{mg})$ & Hermaphrodite & $79.1 \pm 5.3$ & $68.6 \pm 6.0$ & $56.5 \pm 3.9$ \\
& Female & $69.7 \pm 5.2$ & $71.8 \pm 3.4$ & - \\
Seed wet weight $(\mathrm{mg})$ & Hermaphrodite & $7.2 \pm 0.1$ & $9.1 \pm 0.2$ & $8.8 \pm 0.2$ \\
& Female & $8.3 \pm 0.4$ & $8.0 \pm 0.3$ & - \\
Germination success $(\%)$ & Hermaphrodite & 35.0 & 26.1 & $27.3(22)$ \\
& Female & 11.1 & 39.1 & - \\
\hline
\end{tabular}

\section{DISCUSSION}

This study examined Pimelea arenaria, a native plant restricted to sand dunes, and listed as Gradually Declining (de Lange et al. 2004), where this decline is anecdotally attributed to recruitment failure. We looked at four populations of Pimelea arenaria to determine if recruitment failure is occurring and, if so, whether this was caused by the floral biology and the pollination regime or by seed germination patterns.

Our data do demonstrate a recruitment gap in Pimelea arenaria at each of the four sites studied, since we failed to locate any seedlings in any population. This recruitment gap is reinforced by measurements of plant size, used as correlates of age. Surface areas of substrate covered by plants demonstrate there are very few small plants, the two smallest being $0.038 \mathrm{~m}^{2}$, plants $20 \times 24 \mathrm{~cm}$ in length and width; it is difficult to envisage individual plants of Pimelea arenaria on a dune growing this much in just a few years, known plants in stable areas having remained largely unchanged over more than a decade (pers. obs.).

Recruitment gaps, as represented by the absence of young size classes in a population's demographics, can be caused by spasmodic regeneration, large numbers of seedlings being recruited into a population only in some years, in response to relatively rare events, such as wet or warm seasons, storms, or other episodic disturbances which modify habitat availability or regeneration success (Andersen 1989). Similarly, Pimelea arenaria seedlings may have very specific microsite requirements, so there is only a narrow window in dune dynamics in which an establishing seedling can survive. For example, occupation of preferred sites may be possible only shortly after new foredunes are formed, the most frequent habitat for Pimelea arenaria along the Manawatu coast being the rear of the foredunes. Further, recruitment gaps in Pimelea arenaria may be due to mast seeding (periodic heavy fruiting years), as seen in several native species (Webb \& Kelly 1993; Kelly et al. 2001), including the endemic Castlepoint treedaisy, Brachyglottis compacta (Kirk) B.Nord. (GLR unpubl. data), though the relatively large numbers of flowers present on Pimelea arenaria plants in most years (pers. obs.) would counter this. However, cohorts are not apparent in Pimelea arenaria, as the populations' plant area distributions, where we equate area of substrate covered to plant age, resemble flattened reverse J curves, with the smallest size classes absent or under-represented. Though it is possible that cohort structures might have gradually dissolved if growth rates were variable, and/or age was poorly related to size, the missing youngest age classes in Pimelea arenaria would appear to cover decades, a longer time span than would be adaptive for cohort regeneration episodes in such a dynamic environment.

The distributions of maximum heights (data not presented) also suggest that recruitment failure is occurring in these populations, though the significant differences in plant height observed between sites are more likely to be related to substrate mobility than age. Plants in sand dunes are repeatedly buried and uncovered by sand movements (Sykes \& Wilson 1990; Yanful \& Maun 1996; Maun 1998; Milne \& Sawyer 2002), and affected by wind, slope, and sand supply (Maun \& Lapierre 1986; Sykes \& Wilson 1990; Wilson \& Sykes 1999). Thus, surface 
area of substrate covered is a better correlate of age for Pimelea arenaria than is height, so there is no evidence of differences in population demographics between the four sites.

This characteristic ability to withstand burial by sand (Sykes \& Wilson 1990; Yanful \& Maun 1996; Maun 1998) is especially critical for seedlings of dune species (Maun \& Lapierre 1986). It is possible that the rate of sand deposition has increased in areas which Pimelea arenaria currently occupies, and that this now exceeds the emergence depth for seeds and/or the growth rate of seedlings. Dunes currently accrete on the Manawatu coast (affecting the Himatangi and Tangimoana sites) at a rate of $0.5-1 \mathrm{~m} \mathrm{yr}^{-1}$ with deposition of $20 \mathrm{~m}^{3}$ of sand per metre of dune width per year (Johnson 1987 in Hesp 2001), which is extremely fast. However, at Castlecliff and Castlepoint the dunes are much less dynamic, even though some sites are steep; yet there is no apparently suitable habitat for seedlings.

It is possible that the absence of smaller plant sizes is simply due to misinterpretation of dense clumps of young individuals, as it is difficult to determine what an individual actually is, in an environment where no clear rooting main stem is visible, and excavations are not permissible. However, even the smallest "individuals" appear single-stemmed and have features of mature wood. Less probably, seemingly separate plants in close proximity to each other might actually be exposed portions of the same individual, with points of attachment buried beneath the sand. If not confounded by intermingled individuals, the average nearest neighbour distances were large and variable at all sites demonstrating diffuse population structures. Only at Castlepoint were there signs of clumping, and even then the average distance between plants was nearly $1 \mathrm{~m}$. It is unlikely that functional yet buried stems of Pimelea arenaria could survive across such a span.

This recruitment problem appears to be confined, amongst the dune shrubs, to Pimelea arenaria, as the other common mid and rear dune species of this area, Ozothamnus leptophyllus (Forst.) Brietw. \& Ward and Coprosma acerosa A.Cunn., appear to be reproducing adequately (pers. obs.). The locally extremely rare Pimelea "Tangimoana"/"Himatangi"/ "Turakina", a short-lived, lax, hairless subshrub, probably of specific rank (Burrows 2001), fruits prolifically while young, and has readily identifiable seedlings 3-8 cm high, soft, and single-stemmed, occurring in the marginal vegetation around wet hollows at Tangimoana (pers. obs.). These seedlings originate from plants cultivated from Turakina seed, and planted at Tangimoana in the early 1990s. Subsequent plantings also produced seedlings, though many were lost as the wetland infilled (pers. obs.). The absence of juveniles in Pimelea arenaria cannot be controverted.

Reproductive failure is a plausible explanation for a lack of recruitment in Pimelea arenaria. With a gynodioecious species, only a proportion of individuals can set seed if pollen supply is limiting and/or the species is obligatorily outcrossing. Thus, some gender ratios may not engender adequate quantities of seed to sustain population recruitment. In these lower North Island sites, gender ratios in Pimelea arenaria were highly variable, although hermaphrodite plants were always much more common. The only other gender ratios recorded for Pimelea (Burrows 1958, 1960) differ from the present study, all being close to $1: 1$ throughout the flowering season. P. prostrata, listed as Data Deficient in terms of its rarity (de Lange et al. 2004), has a ratio of 1:10 (female: hermaphrodite) in the early part of the flowering season (Burrows 1960), and this is closest to the ratios recorded in this study. Only one-time counts of the gender ratio were made in this study and it is possible, given the results of Burrows (1960), that the ratio of female to hermaphrodite plants changes through and between flowering seasons, affecting seed set variably over time. However, since there appear to be sufficient flowers in these populations, especially hermaphroditic ones, at least moderate levels of seed production are possible.

Seed production in Pimelea arenaria may be inhibited by pollination failures. The pollen:ovule ratio reflects the pollen vectors associated with a plant, there being a strong correlation between the pollination ecology of a plant and the amount of pollen produced (Cruden 1977). The ratio found in this study indicates that Pimelea arenaria is an outcrossing species with a tendency towards facultative out-crossing, so pollination is likely to be by unreliable and unspecialised vectors, such as fly species (Cruden 1977). Small dipterans were observed visiting Pimelea arenaria at Tangimoana and Castlepoint in December 2002 and January 2003, although pollination behaviour could not be observed. Burrows (1960) noted that nectar is produced by both female and hermaphrodite flowers. Here nectar was quantified as c. 0.4 and c. 0.9 joules for hermaphrodite flowers at Castlecliff and Castlepoint, although there is no obvious explanation for this site difference. This nectar production is extremely small compared with other New Zealand plants, with flowers pollinated by entomophilous species producing 
nectar ranging from 1.5 to 6.7 joules (Castro \& Robertson 1997). Both female and hermaphrodite plants are capable of producing fruit and seed, and neither gender appears pollen limited in nature. Pollinator-exclusion treatments did demonstrate that excluding small animals reduced fruit set to (near) zero in female plants, and negligibly, if at all, in hermaphrodite plants. Hermaphrodite plants are not obligatorily outcrossing as they produce more fruit than females due to autonomous self-pollination (cf. Burrows 1960). Given the greater proportion of hermaphrodite plants in the population and absence of pollen limitation, lack of fruit and seed set seems unlikely as an explanation for the observed regeneration failure in Pimelea arenaria.

Contrary to Metcalf (1995), who suggested that only cold storage stratification and scarification could induce germination in Pimelea seed (except Pimelea tomentosa), and even then germination could not be expected within 12 months, $29 \%$ of the seeds collected at Castlepoint germinated at $20^{\circ} \mathrm{C}$, though there were significantly lower germination rates in naturally pollinated seed from female plants. Some seed stored in the fridge at $4^{\circ} \mathrm{C}$ also germinated, so temperatures do not appear to be limiting. This prompt germination suggests that Pimelea arenaria seed does not add to seed banks, which would be a dangerous strategy in an environment as dynamic as dunelands, where seed may rapidly be deeply buried for prolonged periods (Zhang \& Maun 1994).

Each Pimelea arenaria seed is enclosed in a small fruit. The fruit pulp of some New Zealand plant species has been shown to have inhibitory effects on seed germination (Burrows 1989; Partridge \& Wilson 1990; Bannister \& Bridgman 1991; Fountain \& Outred 1991). This cannot apply in Pimelea arenaria as germination of seed was observed through the pulp of fruit in cold storage. By contrast, it is possible that the presence of fruit pulp is advantageous for germination, releasing additional moisture as it breaks down and so improving the survival of seedlings, important in dune ecosystems as one of the main physiological stresses is desiccation (Permadasa \& Lovell 1975; Maun 1981; Boorman \& Fuller 1984). However, much Pimelea arenaria seed should germinate readily regardless of whether the pulp persists or has been removed, e.g., by gut passage or sand abrasion. Seed germination rates do not appear to be an issue in the recruitment failure of this species.

Pimelea arenaria plants produce large numbers of flowers, which result in substantial numbers of ripe fruit when these are protected from removal agents (Dawson 2003), numbers which are perhaps adequate for regeneration. However, frugivores, which are abundant at all four sites, may ingest fruit and seed, either directly from the plant or after it falls onto the substrate, to further disperse or digest it. Alternatively, seedlings may be consumed by herbivores such as rabbits or mice shortly after germination. The lack of seedlings in the study populations demonstrates that seeds do not germinate readily in the wild, or they germinate but do not establish, or the seedlings establish but do not escape herbivory long.

\section{Conclusion}

All the populations in this study show a bias towards medium to larger (and so presumably older) plants with no seedlings, indicating recruitment failure in Pimelea arenaria. It is clear that the plants produce flowers which can be fertilised, and pollen that can fertilise ovules. Further, pollination vectors exist which transfer the pollen, though viable seed can be produced even without out-crossing and can germinate (in controlled conditions). Thus, there is no pollination failure. Therefore, seed and seedling survival appears to be the vulnerable stage in the life history of Pimelea arenaria, causing the recruitment failure. The relative roles of dune dynamics and native and exotic predators in this recruitment failure require investigation.

\section{ACKNOWLEDGMENTS}

This study was funded by the Graduate Research Fund (Massey University), the Massey University Research Fund, and the Coombs Memorial Scholarship. Grateful thanks are extended to Basil Sexton for access to the Himatangi site; Craig McGill, Seed Technology, Massey University, and Astrid Dijkgraaf, Vivienne McGlynn, and Garry Foster, of the Department of Conservation, for all their assistance; Kristina Salzer, Rowena Teal, Kiryn Weaver, and Mark Hamer for their help in the field; and Rosemary van Essen for figures. We thank Colin Webb and an anonymous reviewer for helpful comments, and Ian Henderson for statistical advice.

\section{REFERENCES}

Adolf W, Heckler E 1982. On the active principles of Thymelaeaceae. II. Skin irritant and co-carcinogenic diterpenoid factors from Daphnopsis racemosa. Planta Medica 45: 177-182. 
Adolf W, Seip EH, Heckler E, Dossaji SF 1988. Irritant principles of the mezereon family Thymelaeaceae. New skin irritants and tumour promoters of the daphnane and 1-Alpha alkyldaphnane type from Synaptolepis kirkii and Synaptolepis retusa. Journal of Natural Products (Lloydia) 51: 662-674.

Allan HH 1961. Flora of New Zealand. Vol. I. Wellington, Government Printer.

Andersen AN 1989. How important is seed predation to recruitment in stable populations of long-lived perennials? Oecologia 81: 310-315.

Bannister P, Bridgman J 1991. Responses of three species of Pseudopanax to low temperature stratification, removal of fruit flesh, and application of gibberellic acid. New Zealand Journal of Botany 29: 213-216.

Boorman LA, Fuller RM 1984. The comparative ecology of two sand dune biennials: Lactuca virosa L. and Cynoglossum officinale L. New Phytologist 69: 609-629.

Burrows CJ 1958. Variation in some species of the genus Pimelea. Unpublished MSc thesis, Canterbury College, University of New Zealand, Christchurch, New Zealand.

Burrows CJ 1960. Studies in Pimelea. I - The breeding system. Transactions of the Royal Society of New Zealand 88: 29-45.

Burrows CJ 1989. Patterns of delayed germination in seeds. New Zealand Natural Sciences 16: 13-19.

Burrows CJ 2001. Characterising Pimelea "Turakina". Conservation Science Newsletter 40/41: 10-11.

Castro I, Robertson AW 1997. Honeyeaters and the New Zealand forest flora: the utilisation and profitability of small flowers. New Zealand Journal of Ecology 21: 169-179.

Cruden RW 1977. Pollen-ovule ratios: A conservative indicator of breeding systems in flowering plants. Evolution 31: 32-46.

Dawson PAC 2003. Regeneration of the native sand dune plant Pimelea arenaria in the lower North Island, New Zealand. Unpublished MSc thesis, Massey University, Palmerston North, New Zealand.

de Lange PJ, Norton DA, Heenan PB, Courtney SP, Molloy BPJ, Ogle CC, Rance BD, Johnson PN, Hitchmough R 2004. Threatened and uncommon plants of New Zealand. New Zealand Journal of Botany 42: 45-76.

Esler AE 1978. Botany of the Manawatu District, New Zealand. Wellington, Government Printer.

Fountain DW, Outred HA 1991. Germination requirements of New Zealand plants: a review. New Zealand Journal of Botany 29: 311-316.
Freeman PW, Ritchie E, Taylor WC 1979. Constituents of Australian Pimelea spp. 1. Isolation and structure of the toxin of Pimelea simplex and Pimelea trichostachya form B responsible for St George disease of cattle. Australian Journal of Chemistry 32: 2495-2506.

Hafez A, Adolf W, Heckler E 1983. Active principles of the Thymelaeaceae. 3. Skin irritant and co-carcinogenic factors from Pimelea simplex. Planta Medica 49: 3-8.

Heads MJ 1994. Biogeography and biodiversity in New Zealand Pimelea (Thymelaeaceae). Candollea 49: 37-53.

Hesp PA 2001. The Manawatu dunefield: environmental change and human impacts. New Zealand Geographer 57: 33-40.

Hilton M, Macauley U, Henderson R 2000. Inventory of New Zealand's active dunelands. Science for Conservation 157. Wellington, Department of Conservation.

Kearns CA, Inouye DW 1993. Techniques for pollination biologists. USA, University of Colorado, University Press.

Kelly D, Hart DE, Allen RB 2001. Evaluating the wind pollination benefits of mast seeding. Ecology 82: $117-126$.

Maun MA 1981. Seed germination and seedling establishment of Calamovilfa longifolia on Lake Huron sand dunes. Canadian Journal of Botany 59: 460-469.

Maun MA 1998. Adaptations of plants to burial in coastal sand dunes. Canadian Journal of Botany 76: 713-738.

Maun MA, Lapierre J 1986. Effects of burial by sand on seed germination and seedling emergence of four dune species. American Journal of Botany 73: $450-55$.

McKenna MA, Thomson JD 1988. A technique for sampling and measuring small amounts of floral nectar. Ecology 69: 1306-1307.

Metcalf L 1995. The propagation of New Zealand native plants. Auckland, Godwit Publishing. 75 p.

Milne R, Sawyer J 2002. Coastal dune vegetation in Wellington Conservancy. Current status and future management. Wellington, Department of Conservation.

Parlane BJ 1925. The Pimeleas of the Cass Valley. Unpublished BSc(Hons) thesis, Canterbury College, University of New Zealand, Christchurch, New Zealand.

Partridge TR, Wilson MD 1990. A germination inhibitor in the seeds of mahoe (Melicytus ramiflorus). New Zealand Journal of Botany 28: 475-478. 
Permadasa MA, Lovell PH 1975. Factors controlling germination of some dune annuals. Journal of Ecology 64: 41-59.

Pettit GR, Zou J-C, Goswami A, Cragg GM, Schmidt JM 1983. Anti neoplastic agents. 88. Pimelea prostrata. Journal of Natural Products (Lloydia) 46: 563-568.

Quinn GP, Keough MJ 2002. Experimental design and data analysis for biologists. UK, Cambridge University Press. P. 65.

S-Plus 1998. S-Plus 4.5. Seattle, Mathsoft.

Sykes MT, Wilson JB 1990. An experimental investigation into the response of New Zealand sand dune species to different depths of burial by sand. Acta Botanica Neerlandica 39: 171-181.

Systat 1996. SYSTAT for Windows, version 6.0. Evanston, Illinois, Systat Inc.
Webb CJ, Kelly D 1993. The reproductive biology of the New Zealand flora. Trends in Ecology \& Evolution 8: 442-447.

Wilson JB, Sykes MT 1999. Is zonation on coastal sand dunes determined primarily by sand burial or by salt spray? A test in New Zealand dunes. Ecology Letters 2: 233-236.

Yanful M, Maun MA 1996. Effects of burial of seeds and seedlings from different seed sizes on the emergence and growth of Strophostles helvola. Canadian Journal of Botany 74: 1322-1330.

Zayed S, Adolf W, Heckler E 1982. Active principles of the Thymelaeaceae. 1. The irritants and carcinogens of Pimelea prostrata. Planta Medica 45: 67-77.

Zhang J, Maun MA 1994. Potential for seed bank formation in seven Great Lakes sand dune species. American Journal of Botany 81: 387-394. 